\title{
ASAS PEMISAHAN HORIZONTAL (HORIZONTALE SCHEIDING BEGINSEL) DAN ASAS PERLEKATAN (VERTICALE ACCESSIE) DALAM HUKUM AGRARIA NASIONAL
}

\author{
Sri Harini Dwiyatmi \\ Fakultas Hukum Universitas Kristen Satya Wacana \\ Korespondensi: rini.suyanto@gmail.com
}

Naskah diterima: 23 Maret 2020|Direvisi: 26 Maret 2020|Disetujui: 30 Oktober 2020

\begin{abstract}
Abstrak
Hukum Agraria Nasional atau Hukum Tanah Nasional yang dituangkan dalam UU No. 5 Tahun 1960 tentang Peraturan Dasar Pokok-pokok Agraria dibangun dari hukum adat sebagai asli hukum bangsa Indonesia menjadikan konsepsi-konsepsi, asas, kaidah dalam hukum adat yang tidak bertentangan dengan jiwa bangsa Indonesia berlaku untuk membangun hukum agraria nasional sejak tahun 1960. Termasuk di dalamnya asas pemisahan horizontal dianut oleh UUPA. Ternyata penganutan asas pemisahan horizontal ini tidaklah mutlak, sebab berlaku juga asas perlekatan atau verticale accessie. Sejak awal hukum agraria nasional mengatur asas horizontale scheiding beginsel juga verticale accessie. Tulisan ini hendak menunjukkan perwujudan asas pemisahan horizontal dan verticale accessie terletak di mana dalam hukum agraria nasional ini.
\end{abstract}

Keywords: Asas Pemisahan Horizontal; Asas Accessie; Hukum Agraria Nasional.

\begin{abstract}
The National Land Law, regulated in Law No. 5 of 1960 concerning Basic Regulations on Agrarian Principles, was formed from the Indonesian customary law as the original character of the Indonesian people. From 1960, the principles in the national customary law, which are suitable with the Indonesian features, have contributed to the National Land Law development. One of its Principles is the Principle of Horizontal Separation. This Principle is not absolute as the Principle of vertical accesssie may be applied as well. This research observed the application of the Principle of Horizontal Separation and the Principle of vertical accessie in the National Land Law.
\end{abstract}

Keywords: The Principle of Horizontal Separation; The Principle of Vertical Accessie; Agrarian Law. 


\section{PENDAHULUAN}

Pernyataan bahwa hukum agararia nasional Indonesia dibangun dari hukum adat Indonesia, bermakna bahwa konsepsi-konsepsi dalam hukum adatlah yang digunakan untuk membangun hukum agraria nasional. Ada banyak konsepsi dalam hukum adat antara lain: konsepsi hubungan abadi tanah dengan masyarakatnya, konsepsi kepala adat sebagai pengatur wilayah adat, konsepsi wilayah adat hanya untuk anggota persekutuan adat, konsepsi prinsip terang dan tunai dalam jual beli tanah, dan konsepsi pemilikan tanah berbeda dengan pemilikan bangunan, tanaman dan sejenisnya yang ada di atas tanah. Hal demikian disebut asas pemisahan horizontal. Konsepsi yang terakhir inilah yang akan menjadi focus penulisan ini.

Tulisan yang semula bersumber dari penelitian ini hendak mempersoalkan bahwa hukum agraria nasional yang tertuang dalam UndangUndang No. 5 Tahun 1960 tentang Peraturan Dasar Pokok-Pokok Agraria beserta peraturan pelaksananya (selanjutnya disebut dengan UUPA) hanya menganut asas pemisahan horizontal saja. Hal ini dipermasalahkan oleh karena lebih dalam pengajaran mata kuliah hukum agraria selalu dikatakan bahwa hukum agraria menganut asas pemisahan horizontal karena hukum agraria dibangun dari hukum adat, maka konsepsi-konsepsi / prinsipprinsip / asas-asas dalam hukum adat secara mutatis mutandis dianut juga oleh hukum agraria, meski sering kali tidak nampak tersurat dalam pasalpasal UUPA. Selain itu juga pen- tingnya melihat sistem hukum agraria dalam konteks lebih kini dalam penganutan kedua asas yang disebut dalam judul tulisan ini.

Sebagaimana disebutkan oleh Pasal 5 UUPA:

"Hukum agraria yang berlaku atas bumi, air dan ruang angkasa ialah hukum adat, sepanjang tidak bertentangan dengan kepentingan nasional dan Negara, yang berdasarkan atas persatuan bangsa, dengan sosialisme Indonesia serta dengan peraturan-peraturan yang tercantum dalam undang-undang ini dan dengan peraturan perundang-undangan lainnya, segala sesuatau dengan mengindahkan unsur-unsur yang bersandar pada hukum agama"1

Inilah sebagai dasar hukum bahwa hukum agraria dibangun berdasarkan dari hukum adat. Salah satu asas dalam hukum adat yang di anut dalam hukum agraria adalah asas pemisahan horizontal, telah tidak dianut dalam praktek pemberian kredit dengan jaminan di perbankan. Karena itu fokus penulisan berupa pembuktian bahwa tidak hanya asas pemisahan horizontal saja yang dianut oleh hukum agraria.

Tulisan ini didasarkan pada jenis penelitian hukum normatik. Di mana penelitian demikian hendak menemukan asas, kaidah dalam hukum positif, dengan pendekatan perundang-undangan dan pendekatan konseptual dengan lingkup amatan meliputi UUPA dan peraturan pelaksananya yang terkait dengan asas pemisahan horizontal dan asas aceccssie/perlekatan yaitu UndangUndang Nomor 20 Tahun 2011 tentang Satuan Rumah Susun, Undang-Undang Nomor 4 Tahun 1996 tentang Hak Tanggungan, UndangUndang Nomor 28 Tahun 2002 
tentang Bangunan Gedung, Peraturan Menteri Dalam Negeri Nomor 1 Tahun 1977, Peraturan Pemerintah Nomor 24 Tahun 1997 tentang Pendaftaran Tanah, dan Peraturan Pemerintah Nomor 40 Tahun 1996 tentang Hak Guna Usaha, Hak Guna Bangunan dan Hak Pakai Atas Tanah.

\section{PEMBAHASAN}

\section{Hakekat Asas Pemisahan Horizontal dan Asas Perlekatan}

Uraian pada subbab ini lebih pada hakekat normatif dari kedua asas di atas. Hubungan antara manusia dengan tanah sangat erat sehingga dirasakan mempunyai pertalian yang berakar dalam alam pikiran. Hal ini dapat dimengerti dan dipahami, karena tanah merupakan tempat tinggal, tempat pemberi makan, tempat manusia dilahirkan, dan tempat manusia dimakamkan. Jadi, tanah sangat dibutuhkan oleh setiap manusia baik dalam skala lingkup kecil yang hanya sebatas untuk kebutuhan tempat tinggal, maupun dalam skala besar yaitu untuk kebutuhan sosial maupun usaha. Perkembangan dan pertambahan manusia tersebut membawa konsekuensi logis tuntutan kebutuhan tanah sebagai suatu hal pokok yang harus dimiliki. Hal ini memberikan pengertian bahwa pentingnya tanah bagi kehidupan manusia untuk selalu berusaha agar dapat memiliki dan menguasai tanah. Masyarakat hukum sebagai kesatuan dengan tanah yang didudukinya, terdapat hubungan yang erat sekali. Hubungan yang bersumber pada pandangan yang bersifat religio-magis, menyebabkan masyarakat hukum memperoleh dan untuk menguasai tanah tersebut, memanfaatkan tanah itu, memungut hasil dari tumbuh-tumbuhan yang hidup di atas tanah itu, juga memburu terhadap binatang-binatang yang hidup disitu. Hak masyarakat hukum atas tanah ini disebut hak pertuanan atau ulayat.

Hukum Tanah Nasional yang tertuang dalam UUPA, didasarkan pada hukum adat. Hal ini dapat diketahui dari rumusan Pasal 3 dan Pasal 5 UUPA, yaitu,

Dengan mengingat ketentuanketentuan dalam pasal 1 dan 2 pelaksanaan hak-ulayat dan hakhak yang serupa itu dari masyarakat-masyarakat hukum adat, sepanjang menurut kenyataannya masih ada, harus sedemikian rupa sehingga sesuai dengan kepentingan nasional dan Negara, yang berdasarkan atas persatuan bangsa serta tidak boleh bertentangan dengan undang-undang dan peraturan-peraturan lain yang lebih tinggi; Hukum agraria yang berlaku atas bumi, air dan ruang-ruang angkasa ialah hukum adat, sepanjang tidak bertentangan dengan kepentingan nasional dan Negara, yang berdasarkan atas persatuan bangsa, dengan sosialisme Indonesia serta dengan peraturanperaturan yang tercantum dalam undang-undang ini dan dengan peraturan perundangan lainnya segala sesuatu dengan mengindahkan unsur-unsur yang bersandar pada hukum agama. ${ }^{2}$

Pengaturan pada pasal tersebut berkonsekuensi, konsepsi-konsepsi dalam hukum adat digunakan oleh hukum tanah/agraria nasional. Dengan demikian hukum agraria nasional mengandung asas, konsepsikonsepsi hukum adat. ${ }^{3}$ Salah satu asas yang dianut oleh hukum agraria

Pasal 3 dan 5 UU No. 5 Tahun 1960 tentang Peraturan Dasar Pokok-Pokok Agraria.

Boedi Harsono, Hukum Agraria Indonesia, Sejarah Pembentukan Undang-undang Pokok Agraria, Isi dan Pelaksanaanya (Ed. Revisi, Djambatan 1999) 225-234. 
nasional adalah asas pemisahan horizontal. Asas pemisahan horizontal adalah asas yang berprinsip bahwa setiap perbuatan hukum mengenai hak-hak atas tanah, tidak dengan sendirinya meliputi perbuatan hukum atas benda-benda yang ada di atas tanah tersebut.

Makna asas pemisahan horizontal ini bisa disimak juga dari pendapat beberapa ahli seperti Imam Sudiyat ${ }^{4}$ menyatakan hal yang mirip bahwa asas pemisahan horizontal adalah pemilikan atas tanah dan benda atau segala sesuatu yang berdiri di atas tanah itu terpisah. Asas pemisahan horizontal memisahkan tanah dengan benda lain yang melekat pada tanah itu. Dalam kaitannya dengan ini, pendapat Ter Haar yang dikutip Imam Sudiyat ${ }^{5}$ menyatakan bahwa tanah terpisah dari segala sesuatu yang melekat padanya atau pemilikan atas tanah terlepas dari benda yang ada di atasnya sehingga pemilik tanah dan bangunan yang berada dia tasnya dapat berbeda6. Secara singkat, Djuhaendah Hasan ${ }^{7}$ menyatakan bahwa asas pemisahan horizontal memisahkan tanah dari segala benda yang melekat pada tanah tersebut. Betty Rubianti mengutip pendapat Boedi Harsono ${ }^{8}$ menyatakan bahwa dengan adanya asas pemisahan horizontal ini, subjek pemegang hak atas tanahnya bisa berbeda dengan subjek atas kepemilikan bangungan gedung, sehingga tanah dan bangunan akan tunduk pada hukum yang berbeda, tanah akan tunduk pada hukum tanah, sedangkan bangunannya akan tunduk pada hukum perhutangan yang mengatur kekuasaan hak atas benda bukan tanah. Jadi dalam hukum pertanahan, menganut asas pemisahan horisontal secara mutatis mutandis dimana asas ini menegaskan bahwa tanah dan bangunan bukanlah merupakan suatu kesatuan. Mengesampingkan asas perlekatan/ accessie yang dianut oleh KUHPerdata Pasal 500 dan Pasal 571.

Dalam rangka membangun hukum tanah nasional, hukum adat merupakan sumber utama untuk memperoleh bahan-bahannya, berupa konsepsi, asas-asas dan lembaga hukumnya, untuk dirumuskan menjadi norma-norma hukum yang tertulis, yang disusun menurut sistem hukum adat. Hukum tanah baru yang dibentuk dengan menggunakan bahanbahan dari hukum adat, berupa norma-norma hukum yang dituangkan dalam peraturan-peraturan perundang-undangan sebagai hukum yang tertulis, merupakan hukum tanah nasional positif yang tertulis. UUPA merupakan hasilnya yang pertama. Fungsi hukum adat sebagai sumber utama dalam pembangunan hukum tanah nasional inilah yang dimaksudkan dalam konsiderans UUPA, bahwa hukum tanah nasional berdasarkan atas hukum adat. Dianutnya asas pemisahan horizontal pada hukum adat oleh sistem hukum tanah nasional menurut UUPA,

Imam Sudiyat, Hukum Adat Sketsa Asas (Liberty 1981) 54.

Ibid.

Boedi Harsono, Op.Cit.

Djuhaendah Hasan, Lembaga Jaminan Kebendaan Bagi Tanah Dan Benda Lain yang Melekat Pada Tanah Dalam Konsepsi Penerapan Asas Pemisahan Horisontal (PT. Citra Aditya Bakti 1996) 65.

$8 \quad$ Betty Rubianti, Yani Pujiwati, Mulyani Djakaria, 'Asas Pemisahan Horizontal dalam Kepemilikan Hak Atas Tanah dan Bangunan Satuan Rumah Susun Bagi Masyarakat Berpenghasilan Rendah (MBR)' (2015) 17 (2) Jurnal Sosiohumaniora 94, 96. 
menjadikan hukum tanah nasional mengacu juga pada asas-asas hukum adat tersebut.

Mengenai asas accessie atau asas natrekking yang diterjemahkan dalam bahasa Indonesia sebagai asas perlekatan. Asas perlekatan diberikan pengertian sebagai bangunan-bangunan dan benda-benda atau tanaman yang terdapat di atas tanah merupakan satu kesatuan dengan tanah, serta merupakan bagian dari tanah yang bersangkutan. Dengan demikian, pengertian hak atas tanah meliputi juga kepemilikan bangunan dan tanaman yang ada diatas tanah yang menjadi hak seseorang, kecuali kalau ada kesepakatan sebaliknya dengan pihak lain.

Asas ini diatur dalam Buku II KUHPerdata

Pasal 500: Segala sesuatu yang termasuk dalam suatu barang karena hukum perlekatan, begitu pula segalahasilnya, baik hasil alam, maupun hasil usaha kerajinan, selama melekat pada dahan atau akarnya, atau terpaut pada tanah, adalah bagian dan barang itu. ${ }^{9}$

Pasal 571: Hak milik atas sebidang tanah meliputi hak milik atas segala sesuatu yang ada di atasnya dandidalam tanah itu. Di atas sebidang tanah, pemilik boleh mengusahakan segala tanaman danmendirikan bangunan yang dikehendakinya. ${ }^{10}$

Hal ini tidak mengurangi pengecualian dalam Bab IV dan VI buku ini. Di bawah tanah itu boleh membangun dan menggali dan mengambil semua hasil yang diperoleh dari galian itu; hal ini tidak mengurangi perubahanperubahan dalam perundang-undangan dan peraturan pemerintah ten- tang pertambangan, pengambilan bara, dan barang-barang semacam itu.

Pasal 601: menyebutkan segala sesuatu yang dibangun di atas pekarangan adalah milik si pemilik tanah, asalkan bangunan itu melekat pada tanah. ${ }^{11}$

Ketiga pasal tersebut secara prinsip menyatakan bahwa hak milik atas sebidang tanah termasuk pula kepemilikan atas segala sesuatu yang ada di atas tanah maupun di dalam tanah tersebut. Dengan kata lain, kepemilikan atas tanah meliputi pula kepemilikan atas bangunan dan segala sesuatu yang ada di atasnya, karena bangunan merupakan bagian dari tanah tersebut. Dengan demikian dalam asas accessie dapat dimiliki segala sesuatu yang ada diatas tanah. Hal ini sekali lagi ditegaskan oleh Klyen ${ }^{12}$ berikut ini:

"dalam perumusan benda tidak
bergerak dimana disebutkan bahwa
perlekatan dari suatu benda
bergerak yang tertancap dan terpaku
pada benda tidak bergerak" maka secara yuridis harus dianggap sebagai benda tidak bergerak pula. Perlekatan itu harus sedemikian rupa sehingga apabila keduanya dipisahkan satu sama lain, maka ini akan menimbulkan kerusakan kepada salah satu atau kedua benda itu. Juga dengan penafsiran hukum otentik yang dapat dilakukan dengan cara melihat penjelasan dari pembuatan UU itu sendiri. Simpulan yang dapat diambil adalah sertifikat hak atas tanah yang menjadi alat bukti kepemilikan hak atas tanah sekaligus menjadi alat bukti atas segala sesuatu yang berdiri di atas tanah itu, merupakan perwujudan dari asas 
perlekatan vertikal/accessie. Sebagian sertifikat hak atas tanah merupakan implementasi dari asas perlekatan vertikal dan sebagian sertifikat sebagai perwujudan dari asas pemisahan horizontal. Akibatnya dalam proses pembuktian hukum atas bukti kepemilikan hak atas tanah menjadi beranekaragam. Seseorang yang memiliki sertifikat hak atas tanah secara serta merta menganggap dirinya adalah pemilik atas segala benda tidak bergerak yang berdiri di atasnya.

\section{Asas Pemisahan Horizontal dan Asas Perlekatan dalam Hukum Agraria Nasional}

\section{a. Asas Pemisahan Horizontal}

Bagaimana sebenarnya pemuatan asas pemisahan horizontal atau horizontale scheiding beginsel dalam hukum agraria yang dituangkan dalam UUPA? Memang tidak akan pernah ditemukan dalam suatu rumusan pasal meskipun hanya tersirat. Pernyataan pada Pasal 3 dan Pasal 5 UUPA di mana hukum adat digunakan untuk membangun hukum agraria lebih bermakna sebagai jiwa dari hukum adat yang digunakan untuk membangun hukum agraria nasional. Jiwa dalam hukum adat itu berupa konsepsi-konsepsi dalam hukum adat yang dituangkan dalam hukum agraria nasional. asas pemisahan horizontal ini akan ditelusur di mana saja terdapat perwujudan asas pemisahan horizontal dalam UUPA.

Asas pemisahan horizontal merupakan salah satu konsepsi dalam hukum adat. Memahami makna asas pemisahan horizontal dalam hukum adat adalah bahwa bangunan dan atau bangunan dan tanaman yang ada di atas tanah bukan merupakan bagian dari tanah. Hak atas tanah tidak dengan sendirinya meliputi pemilikan bangunan dan tanaman di atasnya. Perbuatan hukum mengenai tanah tidak dengan sendirinya meliputi perbuatan hukum terhadap bangunan dan atau tanaman. Asas pemisahan horizontal dalam struktur hak atas tanah yang dianut oleh UUPA sebagaimana diatur Pasal 16 UUPA terwujud dalam ${ }^{13}$ :

\section{Hak Guna Usaha}

Hak Guna Usaha adalah hak untuk mengusahakan tanah yang dikuasai langsung oleh negara, dalam jangka waktu tertentu sebagaimana tersebut dalam Pasal 29 UUPA, guna perusahaan pertanian, perikanan atau peternakan atau bisa juga dimaknai sebagai hak yang memberi wewenang kepada pemiliknya untuk usaha-usaha pertanian, perikanan dan peternakan di atas tanah hak guna usaha. Hak Guna Usaha ini merupakan tanah negara yang diberikan kepada perseorangan ataupun badan hukum Indonesia. Pemilik hak guna usaha mengusahakan sesuatu di atas tanah negara yang dimilikinya dengan hak guna usaha tadi. Struktur ini dimengerti bahwa tanah di mana hak guna usaha melekat adalah tanah negara bukan milik pemilik hak guna usaha. Pemilik hak guna usaha hanya memiliki wewenang mengusahakan sesuatu di atas tanah hak guna usaha itu sesuai dengan sifat dari hak tersebut. Dengan demikian "pe-

13 Bandingkan dengan Nasrullah, 'Analisis Hukum Secara Analogi Penerapan Asas Pemisahan Horizontal pada Praktek Jual Beli Tanah Tidak Beserta Dengan Pohon Kelapa di Atasnya di Kecamatan Patilanggio Kabupaten Pohuwato' (2018) 2 (2) Jurnal Hukum Volkgeist 135, 139. 
milik" tanah dengan pemilik sesuatu yang diusahakan di atas tanah berbeda pemilik.

2. Hak Guna Bangunan

Hak Guna Bangunan adalah hak untuk mendirikan dan mempunyai bangunan-bangunan atas tanah yang bukan miliknya sendiri, dengan jangka waktu paling lama 30 tahun. Dengan demikian bisa juga dikatakan sebagai hak yang memberi wewenang kepada pemiliknya untuk mendirikan bangunan di atas tanah milik negara. Pemilik hak guna bangunan memiliki wewenang mendirikan bangunan di atas tanah negara dengan hak guna bangunan. Tanah di mana bangunan didirikan adalah tanah negara, sementara bangunan di atas tanah adalah milik pemilik hak guna bangunan.

3. Hak Pakai

Hak pakai yang diatur pada Pasal 41 sampai Pasal 43, adalah hak untuk menggunakan dan/atau memungut hasil dari tanah yang dikuasai langsung oleh negara atau tanah milik orang lain. Hak pakai memberi wewenang dan kewajiban yang ditentukan dalam keputusan pemberian hak pakai oleh pejabat yang berwenang memberikannya atau dalam perjanjian dengan pemilik tanahnya, yang bukan perjanjian sewa menyewa atau perjanjian pengolahan tanah, atau segala sesuatu asal tidak bertentangan dengan jiwa dan ketentuanketentuan UU ini. Sama halnya dengan Hak Guna Usaha dan Hak Guna Bangunan, Hak pakai ini, pemilikan tanahnya juga berbeda, antara subyek hukum pemilik tanah dengan subyek hukum yang menggunakan hak pakai tadi.

4. Hak Guna Bangunan yang lahir dari hak Pengelolaan dan hak Milik

Pemberian Hak Guna Bangunan yang lahir dari hak pengelolaan menurut Peraturan Menteri Dalam Negeri Nomor 1 Tahun 1977 tentang Tata Cara Permohonan Dan Penyelesaian Pemberian Hak atas bagianbagian Tanah Hak Pengelolaan Serta Pendaftarannya (Selanjutnya disebut Permendagri No. 1 Tahun 1977). Pemegang Hak Guna Bangunan ini haruslah pihak ketiga yang memenuhi persyaratan, memiliki kaitan dengan fungsi dan tugas dari pemilik hak pengelolaan atau sesuai rencana peruntukan dan penggunaan yang telah dipersiapkan oleh pemegang hak pengelolaan yang bersangkutan. ${ }^{14}$ Misalnya Perum Pelabuhan Tanjung Perak Semarang memiliki hak pengelolaan dari negara. Dalam pemilikan hak pengelolaan ini terkait dengan tugas dan fungsi Perum Pelabuhan Tanjung Perak Semarang, yang memerlukan dukungan pihak lain, seperti membutuhkan fasilitas reparasi kapal (dok), lokasi untuk dok ini diberikan dengan hak guna bangunan atau hak pakai yang harus diajukan oleh pemilik dok. Perum Pelabuhan tersebut juga memerlukan fungsi atau fasilitas bongkar muat yang

14 Pasal 1 dan 7 Permendagri No. 1 Tahun 1977 tentang Tata Cara Permohonan Dan Penyelesaian Pemberian Hak atas bagian-bagian Tanah Hak Pengelolaan Serta Pendaftarannya. 
dilakukan oleh pihak ketiga, lokasinya bisa diberikan dengan hak guna bangunan atau Hak Pakai. Struktur demikian menunjukkan adanya asas pemisahan horizontal. Bahwa hukum atas tanah tidak sekaligus hukum atas benda-benda di atas tanah.

Tak beda dengan hak guna bangunan atau hak pakai yang bisa lahir dari hak milik. Bila hak guna bangunan atau hak pakai lahir dari hak milik berdasarkan kesepakatan, maka pemilik hak guna bangunan atau hak pakai memiliki hak untuk mendirikan bangunan atau menggunakan hak pakai di atas hak milik orang lain tadi, selama waktu yang diperjanjikan, dengan sejumlah pembayaran kepada pemilik hak milik juga biaya untuk memperoleh hak guna bangunan dari negara, begitu juga tidak berbeda dengan hak guna bangunan di atas tanah hak pengelolaan.

5. Pasal 44 Ayat (1) UUPA

Pasal ini menyatakan bahwa

'Seorang atau suatu badan hukum mempunyai hak sewa atas tanah, apabila ia berhak menggunakan tanah milik orang lain untuk keperluan bangunan, dengan membayar kepada pemiliknya sejumlah uang sebagai uang sewa'. ${ }^{15}$

Dari bunyi Pasal 44 ayat (1) UUPA di atas menampakan asas pemisahan horizontal terdapat dalam hak sewa untuk bangunan dimana seseorang atau badan hukum menyewa tanah yang milik orang lain dalam keadaan tanah tersebut kosong atau tidak ada bangunannya dengan mem- bayar sejumlah uang sebagai uang sewa yang besarnya ditetapkan atas dasar kesepakatan bersama dan untuk jangka waktu tertentu, dimana dalam jangka waktu tersebut si pemilik tanah memberikan hak kepada si penyewa untuk mendirikan bangunan.

Hak atas Satuan Rumah Susun, Rumah susun adalah bangunan gedung bertingkat yang dibangun dalam suatu lingkungan yang terbagi dalam bagian-bagian yang distrukturkan secara fungsional, baik dalam arah horizontal maupun vertikal dan merupakan satuan-satuan yang masing-masing dapat dimiliki dan digunakan secara terpisah, terutama untuk tempat hunian yang dilengkapi dengan bagian bersama, benda bersama, dan tanah bersama. Ini mengadung makna bahwa rumah susun bisa didirikan di atas tanah milik orang lain dengan jenis hak atas tanah tersebut. Bisa dibangun diatas tanah pihak lain dengan hak guna bangunan ataupun hak pakai bahkan hak pengelolaan.

6. Pasal 4 Ayat (5) Undang-Undang No. 4 Tahun 1997 tentang Hak Tanggungan menyatakan,

"apabila bangunan, tanaman, dan hasil karya sebagaimana dimaksud pada Ayat 4 tidak dimiliki oleh pemegang hak atas tanah, pembebanan hak tanggungan atas benda-benda tersebut hanya dapat dilakukan dengan penandatanganan serta pada akta. Pemberian hak tanggungan yang bersangkutan oleh pemiliknya atau 
yang diberi kuasa untuk itu olehnya dengan akta otentik."

Kalimat yang menyatakan bahwa "apabila bangunan, tanaman, dan hasil karya sebagaimana dimaksud pada Ayat 4 tidak dimiliki oleh pemegang hak atas tanah, === sebagai representasi dari asas pemisahan horizontal".

Pembebanan hak tanggungan atas benda-benda tersebut hanya dapat dilakukan dengan penandatanganan serta pada akta pemberian hak tanggungan yang bersangkutan oleh pemiliknya atau yang diberi kuasa untuk itu olehnya dengan akta otentik.

7. Peraturan Pemerintah No. 40 Tahun 1996 tentang Hak Guna Usaha, Hak Guna Bangunan dan Hak Pakai atas Tanah Dalam pengaturan berdasarkan PP 40 Tahun 1996, perihal terjadinya hak guna bangunan yang diatur pada Pasal 22 sampai Pasal 24 ini, ada dua hal yang hendak dituliskan di sini yang belum termasuk pada uraian di atas tentang hak guna bangunan yaitu:

a) Perihal hak guna bangunan dapat diberikan di atas tanah Hak Pengelolaan. Pemberian hak guna bangunan yang diajukan kepada negara di atas tanah hak pengelolaan oleh mereka yang membutuhkan didasarkan atas usul pemegang hak pengelolaan.

b) Perihal hak guna bangunan dapat diberikan di atas tanah hak milik kepada yang membutuhkan dengan cara pemberian oleh peme- gang Hak Milik dengan akta yang dibuat oeh Pejabat Pembuat Akta Tanah.

Terjadinya hak guna bangunan baik atas hak pengelolaan maupun atas hak milik tersebut memberikan kewajiban kepada yang memohon atas hak guna bangunan tersebut berkewajiban untuk melakukan pendaftaran tanah atas hak yang dimohon sesuai dengan ketentuan yang berlaku untuk itu.

8. Hak atas tanah yang bersifat sementara, meliputi Hak Menumpang. Hak Menumpang yang dimaksud di sini bukan menumpang pada rumah atau bangunan, tetapi Hak Menumpang di atas tanah milik orang lain, yang menurut Boedi Harsono ${ }^{16}$ menumpang untuk mendirikan dan menempati rumah di atas tanah pekarangan milik orang lain; Hak Sewa Tanah Pertanian. UUPA tidak memberikan definisi tentang apa yang dimaksud dengan Hak Sewa Tanah Pertanian. Yang dimaksud dengan Hak Sewa Tanah Pertanian adalah suatu perbuatan hukum dalam bentuk penyerahan penguasaan tanah pertanian oleh pemilik tanah kepada pihak lain (penyewa) dalam jangka waktu tertentu dan sejumlah uang sebagai sewa yang diperjnjian oleh para pihak berdasarkan kesepakatan kedua belah pihak.

\section{b. Asas Perlekatan}

Asas perlekatan atau natrekking atau Verticale Accessie memiliki makna bahwa bangunan dan tanaman/ benda-benda yang ada di atas tanah merupakan satu kesatuan, bangunan 
dan tanaman merupakan bagian dari tanah yang bersangkutan. Penguasaan atas tanah dengan sendirinya juga akan meliputi pula penguasaan atas bangunan dan tanaman yang ada di atas tanah dan perbuatan hukum mengenai tanah dengan sendirinya juga akan meliputi bangunan dan tanaman yang ada diatasnya.

Tidak dianutnya asas perlekatan oleh hukum agraria nasional dipahami sebagai suatu interpretasi karena dijelaskan oleh banyak sumber asas yang sebaliknyalah yang dianut yaitu asas pemisahan horizontal. Namun prinsip ataupun konsepsi pemilikan suatu hak atas tanah meliputi tidak saja atas permukaan bumi yang lazim disebut tanah tetapi juga ruang di atas permukaan bumi (berarti segala sesuatu yang ada di dalam ruang di atas tanah tersebut adalah milik dari pemilik tanah) serta pemilikan ruang di bawah tanah sesuai dengan sifat dari suatu hak, sebagai fakta. Hal ini sejalan dengan pengertian dari hak atas tanah adalah hak yang memberi wewenang untuk menggunakan tanah sesuai dengan sifat dan kemampuannya. Makna sesuai dengan sifat dan kemampuannya adalah sifat dan kemampuan tanah, menunjuk pada penggunaannya. Sebagaimana hak guna usaha, untuk usaha-usaha pertanian, perikanan dan peternakan, hak guna bangunan digunakan untuk mendirikan bangunan di atas sebidang tanah, hak pakai digunakan baik untuk mendirikan bangunan ataupun untuk usaha-usaha pertanian.

Asas perlekatan ini secara tegas dinyatakan dalam Burgerljike Wet
Boek/ Kitab Undang-Undang Hukum Perdata (KUHPer.) sebagai berikut:

segala sesuatu yang termasuk dalam suatu barang karena hukum perlekatan, begitu pula segala hasilnya, baik hasil alam, maupun hasil usaha kerajinan, selama melekat pada dahan atau akarnya, atau terpaut pada tanah, adalah bagian dari barang itu. ${ }^{17} \mathrm{Hak}$ milik atas sebidang tanah meliputi hak milik atas segala sesuatu yang ada di atasnya dan di dalam tanah itu. Di atas sebidang tanah, pemilik boleh mengusahakan segala tanaman dan mendirikan bangunan yang dikehendakinya, hal ini tidak mengurangi pengecualianpengecualian tersebut dalam Bab IV dan VI buku ini. Di bawah tanah itu ia boleh membangun dan menggali sesuka hatinya dan mengambil semua hasil yang diperoleh dari galian itu; hal ini tidak mengurangi perubahan-perubahan dalam perundang -undangan dan peraturan pemerintah tentang pertambangan, pengambilan bara, dan barang-barang semacam itu. ${ }^{18}$ Segala sesuatu yang dibangun di atas pekarangan adalah milik si pemilik tanah, asalkan bangunan itu melekat pada tanah; hal itu tidak mengurangi kemungkinan perubahan termaktub dalam Pasal 603 dan Pasal 604. ${ }^{19}$

Bila dipersingkat akan dapat dimaknai bahwa hak milik atas sebidang tanah mengandung pula kepemilikan atas segala sesuatu yang ada di atas tanah maupun di dalam tanah tersebut. Dengan kata lain, kepemilikan atas tanah meliputi pula kepemilikan atas bangunan yang ada diatasnya, karena bangunan merupakan bagian dari tanah tersebut dan bangunan yang didirikan di atas tanah kepunyaan pihak lain akan menjadi milik pemilik tanah.

Perwujudan asas perlekatan ini dalam hukum agraria nasional tampak dalam hal-hal berikut ini: 
a) Sebagaimana pendapat Boedi Harsono 20 bahwa pemilikan atas sebidang tanah dalam bahasa hukumnya pemilikan hak atas tanah memberi wewenang kepada pemiliknya untuk menggunakan tanah sesuai dengan kemampuan atau sifat tanah tersebut. Kewenangan ini meliputi kewenangan atas permukaan tanah, kewenangan atas ruang di atas permukaan tanah dan kewenangan atas ruang di bawah permukaan bumi atau disebut juga tanah (tubuh bumi). Ini bermakna bahwa hal-hal / benda-benda di atas tanah, kepemilikannya sama dengan kepemilikan tanahnya, perbuatan atas tanah termasuk juga perbuatan atas hal-hal/bendabenda di atas tanah.

b) Dalam Undang-Undang No. 20 Tahun 2011 tentang Satuan Rumah Susun disebutkan bahwa rumah susun adalah bangunan gedung bertingkat yang dibangun dalam suatu lingkungan yang terbagi dalam bagian-bagian yang distrukturkan secara fungsional, baik dalam arah horizontal maupun vertikal dan merupakan satuan-satuan yang masing-masing dapat dimiliki dan digunakan secara terpisah, terutama untuk tempat hunian yang dilengkapi dengan bagian bersama, benda bersama, dan tanah bersama. Dari rumusan ini dimengerti bahwa yang bisa dimiliki dalam satuan rumah susun adalah ${ }^{21}$ : i) bagian-bagian yang dapat dimiliki dan digunakan secara terpisah (bagian hunian)

ii) bagian-bagian yang dapat dimiliki bersama, benda bersama dan tanah bersama, yang berbeda dengan hal diatas poin i).

Dari uraian di atas nampak bahwa ada pemilikan bersama atas benda bersama dan tanah bersama. Kepemilikan bersama atas benda bersama ini makin ditegaskan oleh isi Pasal 1 angka 11 UU Rumah Susun, yang menyatakan bahwa sertifikat hak milik adalah tanda bukti kepemilikan atas satuan rumah susun, berupa sertifikat hak milik atas satuan rumah susun $^{22}$. Pasal ini memberi pengertian bahwa ada penyatuan kepemilikan satuan rumah susun (bangunannya) dengan tanah yang dimiliki secara bersama. Ini menunjukkan bahwa sebagai dianutnya asas perlekatan.

c) Pasal 4 Ayat 4 Undang-Undang Hak Tanggungan

Pasal 4 ayat (4) menyatakan bahwa hak tanggungan dapat juga dibebankan pada hak atas tanah berikut bangunan, tanaman, dan hasil karya yang telah ada atau akan ada yang merupakan satu kesatuan dengan tanah tersebut, dan yang merupakan milik pemegang hak atas tanah yang pembebanannya dengan tegas dinyatakan di dalam akta pemberian hak tanggungan yang bersangkutan.

\footnotetext{
20 Boedi Harsono, Op.Cit. 20.

21 Pasal 1 Angka 11 UU No. 20 Tahun 2011 tentang Satuan Rumah Susun.

22 Ganindra DDM, Kurniawan F, Loc. Cit.
} 
Isi Pasal 4 ayat (4) tersebut memberi pemahaman bahwa pembebanan hak tanggungan bisa dilakukan atas tanah di mana di atas tanah ada benda milik pemegang hak atas tanah atau merupakan satu kesatuan dengan tanah. Ini cerminan asas perlekatan. Di mulai frasa dapat juga .....dan frasa... yang merupakan satu kesatuan dengan tanah dan yang merupakan milik, bunyi lengkapnya:

"Hak Tanggungan dapat juga dibebankan pada hak atas tanah berikut bangunan, tanaman, dan hasil karya yang telah ada atau akan ada yang merupakan satu kesatuan dengan tanah tersebut, dan yang merupakan milik pemegang hak atas tanah yang pembebanannya dengan tegas dinyatakan di dalam akta pemberian hak tanggungan yang bersangkutan."

Frasa ini menampakkan asas perlekatan.

d) Pada Pasal 4 ayat (5) terdapat kata-kata

"jika benda-benda yang ada di atas tanah milik orang lain (asas pemisahan horizontal), hendak dibebani dengan hak tanggungan harus dengan tanda tangan pemiliknya sebagai tanda persetujuan sebagai obyek hak tanggungan (asas natrekking/verticale accessie)."

Ayat ini menyiratkan dianutnya asas perlekatan.

Dengan demikian UndangUndang Hak Tanggungan tidak saja menganut asas pemisahan horizonal tetapi juga asas natrekking/ verticale accessie. Dalam bahasa Undang-Undang
Hak Tanggungan secara jelas terlihat semangat asas perlekatan, sebagai nampak pada Pasal 4 ayat (4) dan ayat (5) UU Hak Tanggungan.

e) Jual beli yang dilakukan oleh dan dihadapan PPAT.

Umumnya dan berdasarkan pengamatan terbatas, jual beli tanah yang aktanya dibuat oleh PPAT lebih sering mengacu pada asas perlekatan daripada menggunakan asas pemisahan horizontal. Konsepsi "tunai, terang dan riil" yang terkandung dalam UUPA tidak bisa mengikuti perkembangan perilaku ekonomi dalam mengembangkan usaha ${ }^{23}$. Hal ini bisa disimpulkan dan dimengerti bahwa jual beli tanah di PPAT hampir tidak pernah mengacu/menggunakan asas pemisahan horizontal, namun menggunakan asas perlekatan. Bisa jadi sudah semakin jarang bahkan sudah tidak pernah lagi asas pemisahan horizontal digunakan, karena memang akan menimbulkan kesulitan sebagaimana pendapat Soepomo di atas.

f) Dalam sistem persertifikatan hak atas tanah menurut Peraturan Pemerintah No. 24 Tahun 1997 tentang Pendaftaran Tanah. Di mana sertifikat merupakan bukti atas hak atas tanah. Ini membuktikan bahwa tanah dan segala sesuatu yang ada di atas tanah adalah milik seseorang yang namanya tercantum dalam sertifikat itu. Tidak dikenal sistem sertifikat dikeluarkan untuk segala sesuatu yang ada di atas 
tanah. Maka sistem demikian menunjukkan bahwa sistem perlekatan dianut oleh sistem pendaftaran tanah yang diatur oleh peraturan pelaksana dari Undang-Undang Pokok Agraria.

g) Asas Pemisahan Horizontal dan Asas Perlekatan dalam Satu Peraturan.

Uraian di atas menemukan masing-masing asas dalam satu pasal saja atau dalam satu peraturan. Ditemukan kedua asas itu ada dalam satu peraturan bahkan dalam satu pasal. Hemat penulis ini merupakan satu perkembangan yang menunjukan semakin relevan asas perlekatan dalam hukum tanah nasional.

Hal tersebut nampak pada Undang-Undang No. 28 Tahun 2002 tentang Bangunan Gedung diatur bahwa pemilik bangungan gedung adalah orang, badan hukum, kelompok orang, atau perkumpulan yang menurut hukum sah sebagai bangunan gedung. Pada prinsipnya, status kepemilikan bangunan gedung harus dibuktikan dengan surat bukti kepemilikan bangunan gedung yang dikeluarkan oleh pemerintah daerah, kecuali bangunan gedung fungsi khusus oleh pemerintah pusat berdasarkan hasil kegiatan pendataan bangunan gedung. Kepemilian bangunan gedung dapat dialihkan kepada pihak lain. Dalam hal terdapat pengalihan hak kepemilikan bangunan gedung, dalam hal pemilik bangunan gedung bukan pemilik tanah, pengalihan hak kepemilikan bangunan gedung harus mendapat persetujuan pemilik tanah. ${ }^{24}$ Menganut asas apakah undangundang di atas? Pernyataan mulai kata

"Dalam hal terdapat pengalihan hak kepemilikan bangunan gedung, dalam hal pemilik bangunan gedung bukan pemilik tanah, pengalihan hak kepemilikan bangunan gedung harus mendapat persetujuan pemilik tanah".

Jadi dengan demikian pemilik bangunan yang berdiri di atas tanah yang bukan miliknya, tidak bisa dengan leluasa, dengan sendirinya menjual bangunan yang ada di atas tanah yang bukan miliknya itu. Harus dengan persetujuan pemilik tanah. Hal ini mirip dengan pemilikan hak guna bangunan.

Undang-Undang Rumah Susun 25 mengatakan dapat dibangun di atas tanah milik orang lain (asas pemisahan horizontal), namun sertifikat hak milik atas satuan rumah susun menyatukan kepemilikan satuan rumah susun dengan tanah bersama menunjukkan adanya asas perlekatan di samping 26 asas pemisahan horizontal..27 Dalam kepemilikan rumah susun melalui pemanfaatan barang milik negara/ daerah berupa tanah dan pendayagunaan tanah wakaf dengan cara sewa dengan bukti kepemilikan berupa sertifikat kepemilikan bangunan gedung satuan rumah susun menunjukan penerapan asas pemisahan horisontal secara konsisten.

Hak atas tanah memang dapat dimiliki atau dikuasai secara bersamasama oleh seluruh pemilik satuan rumah susun dapat berupa hak milik, hak guna bangunan dan atau hak

\footnotetext{
$24 \quad$ Marihot Pahala Siahaan, Hukum Bangunan Gedung di Indonesia (Rajawali Press 1998) 62.

25 UU No. 20 Tahun 2011 tentang Satuan Rumah Susun.

26 Kata 'di samping' adalah kata-kata penulis, Betty Rubiati menyebutnya, masih terpengaruh; Betty Rubiati, Yani Pujiwati dan Mulyani, Op.Cit., 94-99. 
pakai atas tanah negara. Pemilikan atas tanah bersama hemat penulis bukan karena dipengaruhi oleh asas perlekatan, tetapi memang asas perlekatan ini memang sudah ada sejak awal lahirnya UUPA karena memang dianut oleh KUHPerdata dan lebih lanjut dianut oleh Undang-Undang Rumah Susun.

Banyak yang belum menyadari dari dalam hukum agraria, asas pemisahan horizontal saja yang selalu dilihat agar seturut dengan sikap politik UUPA yang tercermin dalam Pasal 3 dan Pasal 5 pada hal suatu sistem hukum dibangun tidak selalu didasarkan pada satu sistem hukum asli sebagai volkgeis suatu masyarakat yang sedang membangun sistem hukum itu, selalu akan dibangun juga.

\section{Urgensi Pengakuan Asas Horizontal dan Asas Perlekatan}

Urgensi Pengakuan Asas Horizontal dan Asas Perlekatan, dapat dikemukanan Pertama, semestinya ketika melakukan pembahasan pada sub bab hubungan fungsional antara hukum adat dan hukum agraria nasional yang akan dimulai dari menunjukkan peran hukum adat dalam pembangunan hukum agraria nasional yang akan dimulai dari konsepti dalam hukum adat mana yang digunakan dalam hukum agraria sebagai konsekuensi rumusan pasal 3 dan 5 UUPA selain dijelaskan konsepti tentang kepemilikan tanah dan kepemilikan benda-benda diatas tanah (asas pemisahan horizontal) juga dijelaskan bahwa ada konsepti lain dari sistem hukum lain turut digunakan dalam hukum agraria nasional yaitu konsepi bahwa kepemilikan tanah adalah sekaligus kepemilikan segala benda yang ada di atas tanah. Di mana hal ini semakin nyata dianut oleh peraturan pelaksana dari UUPA yang lahir lebih kemudian. Dengan demikian ada kejujuran akademik dan ada perkembangan pemikiran berdasarkan konteks yang lebih kini. Hal ini sebagai wujud berpikir kritis sebagai ciri dunia akademik.

Urgensi kedua, untuk memahami bahwa suatu sistem hukum dibangun berdasarkan konteks sosial / masyarakat. Ketika konteks sosial / masyarakat ini berubah maka sistem hukum itu akan menyesuaikan pada konteks masyarakat di mana hukum itu dibangun. Ini nampak pada peraturan pelaksana dari UUPA yang menganut asas perlekatan meski ada juga yang menganut kedua asas tersebut di atas (pemisahan horizontal juga asas perlekatan). Bahwa suatu sistem hukum tidaklah di bangun dalam ruang kosong yang harus dipertahankan secara mutlak berdasarkan konteks sosial / masyarakat suatu masa tertentu terlebih masa yang telah lampau, untuk menghadirkan keadilan maka hukum dibuat tentu berdasarkan rasa keadilan masyarakatnya yang bisa berbeda dari waktu ke waktu.

Urgensi ketiga, perlu makin menegaskan penganutan asas perlekatan. Mengapa karena telah timbul persoalan-persoalan yang sudah lama disinyalir oleh Soepomo yang pernah mengingatkan 28 bahwa jika Indonesia terus menggunakan asas pemisahan horizontal dalam sistem hukumnya maka akan mengalami kesulitan, akan terdapat hambatan dalam pembangunan perekonomian. Hal ini terbukti dilingkungan perbankan sebelum lahirnya Undang-Undang Hak Tanggu-

28 Sri Harini Dwiyatmi, Pengantar Hukum Indonesia (Ed. 2, Ghalia Indonesia 2006) 156. 
ngan sudah menerapkan asas yang sebaliknya dari asas pemisahan horizontal yaitu asas perlekatan. Dalam pemberian kredit perbankan kepada mereka yang membutuhkan, bank selalu mensyaratkan adanya jaminan benda tetap, yang umumnya berupa tanah atau tanah dan segala sesuatu yang ada di atas tanah sebagai jaminan. Jika segala sesuatu yang ada di atas tanah bukan milik dari pemilik tanah maka harus juga menjadi obyek jaminan dengan persetujuan pemilik benda-benda di atas tanah tersebut yang bukan milik pemilik tanah harus disertakan sebagai jaminan dengan turut serta bertanda tangan dalam akta hak tanggungan. Hal demikian bisa dimengerti agar pelepas uang dalam hal ini bank terjamin pelunasan piutangnya dengan benda jaminan yang pasti bisa dieksekusi manakala debiturnya wanprestasi tidak membayar kewajiban hutangnya. Bila benda jaminan dimiliki secara berbeda jika tidak ditempuh sebagai yang diuraikan di muka maka akan sulit melakukan eksekusi atas benda jaminan yang berupa tanah saja atau berupa benda-benda yang di atas tanah saja. Tentang hal ini agaknya negara sadar sehingga dilahirkanlah Undang-Undang hak tanggungan yang mengakomodasi kebiasaan dilingkungan perbankan tadi.

Terdapat dua macam sistem dalam hak guna bangunan diberikan di atas tanah bukan miliknya. Yang pertama dari tanah negara bisa diberikan hak guna bangunan, sehingga bisa mendirikan bangunan di atas tanah negara. Masalahnya adalah apabila hak guna bangunannya berakhir maka tanah harus dikembalikan ke negara. Bagaimana bangunan di atas tanah yang bisa jadi merupakan bangunan permanen, megah bernilai mahal. Jika hak guna bangunan berakhir dengan atau tidak perpanjangan dan pembaharuan hak, akhir masa jangka waku untuk hak guna bangunan itu pasti akan tiba. Bagaimana nasib bangunan yang dibangun di atas tanah bukan milik pemilik bangunan yang megah dan mahal lagi? Apakah pemilik tanah mau membelinya, apakah akan dirubuhkan? Secara teori bangunan yang berdiri di atas tanah milik negara itu menjadi tanggungjawab pemilik hak guna bangunan bukan menjadi tanggungjawab negara sebagai pemberi hak guna bangunan. Yang kedua hak guna bangunan juga bisa diberikan atau lahir dari hak milik perseorangan dengan hak yang sama seperti penerima hak guna bangunan asal dari tanah negara tadi. Jika jangka waktu yang disepakati berakhir bagaimana bangunan yang dibangun di atas tanah hak milik, persoalannya sama dengan uraian di atas, bahwa hak guna bangunan itu menjadi tanggungjawab yang mendirikan bukan tanggungjawab pemilik tanah.

Hak guna bangunan, hak pakai juga bisa lahir dari hak pengelolaan. Permasalahannya sama saja jika jangka waktu hak guna bangunan atau hak pakai berakhir bagaimana status bangunan sebab juga bukan tanggungjawab pemilik hak pengelolaan. Bahkan saat ini ada banyak dibangun apartemen atau rumah susun juga pusat perbelanjaan dibangun di atas hak pengelolaan. Jika jangka waktu berakhir dan pemilik hak pengelolaan tidak membutuhkan bangunan itu dan bangunan itu merupakan apartemen atau pusat 
perbelanjaan (ITC Mangga Dua) ${ }^{29}$ yang "pemilik tanahnya" tidak memerlukan bangunan itu. Dengan kejadian ITC Mangga Dua dan apartemen yang didirikan di atas hak pengelolaan, Elita Rahmi ${ }^{30}$ berpendapat Hak pengelolaan harus dikembalikan pada fungsinya mengingat menimbulkan pemasalahan.

Menyimak uraian di atas dapat dikemukakan pertanyaan, apakah UUPA sebagai sumber hukum agraria nasional sejak awal lahirnya hanya memuat asas pemisahan horizontal? Sejak semula hukum agraria nasional Indonesia tidak tunggal memuat asas ini. mereka yang berkecimpung dalam hukum agararia selalu berpandangan bahwa sejak semula hukum agraria nasional hanya mengenal asas pemisahan horizontal saja. Hal tersebut hemat penulis terpatahkan oleh penelusuran dalam tulisan ini bahkan asas perlekatan ini makin eksis dalam peraturan pelaksana UUPA yang lahir lebih kini.

Berlakunya hukum agraria nasional yang tertuang dalam UUPA mendasarkan diri atas hukum adat, 31 berkonsekuensi konsepsi-konsepsi, asas-asas dalam hukum adat digunakan atau menjadi prinsip dalam UUPA. Menyitir pendapat bahwa hukum merupakan cerminan perilaku masyarakat, bahwa volkgeis masyarakat hendaknya diperhatikan oleh para pembentuk undang-undang agar hukum yang dibuat oleh negara di patuhi masyarakat, maka ketika UUPA disusun di tahun 1960 tidaklah lepas dari situasi dan kondisi diseputar tahun pembentukan UUPA. Semangat kemerdekaan dan kehendak untuk membuat dan menggunakan hukum sendiri asli Indonesia begitu berkobar. Sehingga pilihan jatuh pada prinsipprinsip hukum dan konsepsi-konsepsi hukum adat yang digunakan untuk membangun hukum agraria nasional. Artinya hukum agraria nasional sungguh sebagai cerminan situasi masyarakat Indonesia di masa lahirnya, hukum agraria nasional dibentuk berdasarkan Volksgeist ${ }^{32}$ masyarakat Indonesia. Tidaklah keliru, namun hukum adat sebagai pembentuk hukum agraria nasional tidaklah satusatunya sistem hukum yang digunakan, dan sistem lain yang digunakan adalah asas perlekatan dari sistem hukum perdata barat yang dikodifikasikan dalam Kitab UndangUndang Hukum Perdata (Selanjutnya disebut dengan KUHPerdata).

Urgensi keempat adalah ada permasalahan yang sistemik atas dianutnya sistem bahwa pemilikan tanah tidak dengan sendirinya sebagai pemilikan benda-benda yang ada di atas tanah. Hal ini terbukti telah menciptakan permasalahan antara lain hak guna bangunan dan apartemen di atas hak pengelolaan. Di mana manakala pemegang hak pengelolaan tidak mengijinkan diperpanjangnya hak guna bangunan di atas tanah hak pengelolaan, kemudian bangunan mall dan apartemen di atas

29 Hendra Setiawan Boen, 'Beberapa Pemikiran tentang Asas Pemisahan Horizontal dalam Pertanahan' (Hukum Online, $13 \quad$ Mei <https://www.hukumonline.com/berita/baca/hol16703/beberapa-pemikiran-tentang-asaspemisahan-horizontal-dalam-pertanahan/> diakses 30 Januari 2020.

$30 \quad$ Elita Rahmi, 'Eksistensi Hak Pengelolaan atas Tanah dan Realitas Pembangunan di Indonesia' (2010) 10 (3) Jurnal Dinamika Hukum 339, 350.

31 Sukardi, 'Politik Hukum Terhadap Penggunaan Hak Atas Tanah dan Bangunan Bagi Orang Asing di Indonesia' (1997) XII Yuridika 40 dalam Ganindra DDM dan Kurniawan F, Op.Cit., 229. Sabian Utsman, Dasar-Dasar Sosiologi Hukum (Pustaka Pelajar 2007)151. 
hak pengelolaan. Persoalan ini muncul akibat penganutan asas pemisahan horizontal. Kalangan perbankan sebelum lahirnya Undang-Undang Hak Tanggungan tidak diikuti cukup lama hingga akhirnya lahir Undang-Undang No. 4 Tahun 1996 tentang Hak Tanggungan yang menganut asas perlekatan yang diterapka kalangan perbankan.

Akhirnya negara menyadari bahwa komponen perekonomian utama negara yaitu perbankan tidak menganut sistem yang diletakkan negara dan menciptakan sistemnya sendiri yang lebih sesuai dan adil bagi lingkungan itu. Dengan demikian kekhawatiran Soepomo terjawab dengan dianutnya asas perlekatan dalam Hak Tanggungan. Atas sikap kalangan perbankan ini mengingatkan pada pendapat Paul Laband ${ }^{33}$. Menurutnya ada dua macam undang-undang, yaitu undang-undang dalam arti material dan arti formal. Undang-undang dalam arti material adalah die rechtsverbindliche anordnung eines, yaitu penetapan kaidah hukum dengan tegas sehingga kaidah hukum itu menurut sifatnya mengikat. Agar suatu kaidah (hukum) menjadi undang-undang dalam arti material, diperlukan dua anasir, anasir yang disebut Anordnung, yaitu penetapan peraturan kaidah (hukum) dengan tegas (resmi). Hal ini bisa difahami sebagai suatu proses penetapan oleh lembaga yang diberi wewenangan, karena itu harus ada kaidah yang ditetapkan oleh lembaga yang diberi wewenang negara untuk menjadi undang-undang. Anasir kedua disebut Rechtssatz, yaitu peraturan (kaidah) hukum. Rechtssatz yang tiada anordnung-nya masih merupakan peraturan (kaidah) hukum kebiasaan yang keberlakuannya hanya dikalangan yang meyakininya. Dalam hal ini perbankan.

Adanya aspek sistemik yang penulis maksudkan tersebut di samping menimbulkan persoalan sebagai yang diuraikan di atas juga praktek yang tidak konsisten. Sebagai dikemukakan di atas bahwa pemilikan rumah susun di awal dikatakan terhadap bagian yang terpisah bisa dimiliki secara individual, tetapi ketika dalam pengaturan sertifikat rumah susun dalam Undang-Undang Rumah Susun, rumah susun itu dimiliki juga beserta tanah bersama. Penerapan asas pemisahan horizontal tidak secara konsisten diterapkan, karena dalam peraturan mengenai Rumah Susun tersebut menganut asas perlekatan vertikal yang ternyata dalam sertifikat satuan rumah susun tersebut dicantumkan juga atas hak atas tanahnya, ini bermasalah dalam pemilikan rumah susun bagi warga negara asing yang hanya boleh memiliki rumah susun di atas tanah Hak Pakai.

Sesungguhnya penganutan dua asas dalam hukum agraria nasional jika dicermati telah sejak awak hukum agraria dibangun, sebagai yang dikemukan oleh Boedi Harsono ${ }^{34}$ dalam memberikan pengertian tentang hak atas tanah. Setiap pemilik hak atas tanah selain tanah yang bisa dimiliki bisa dimiliki juga ruang di atas tanah dan ruang di bawah tanah. Artinya pemilik hak atas tanah bisa memanfaatkan ruang di atas tanah dengan membangun atau menanam sesuatu. Mulai tahun 2011 saat lahirnya Undang-Undang Rumah Susun asas pemisahan horizontal dianut 
bersamaan dengan asas perlekatan sebagai dijelaskan dalam uraian di atas. Tentu kita tidak akan mengecilkan pengaturan tersebut dengan mengatakan bahwa pembentuk undang-undang khilaf dalam mengatur hal ini. Kemudian makin jelas ketika undang-undang hak tanggungan lahir di tahun 1997 yang lebih jelas memberi kedudukan asas perlekatan dalam hukum agraria nasional. Halhal demikian dapat difahami sebagai suatu perkembangan dalam kondisi masyarakat yang berbeda dengan masa disusunnya hukum agraria nasional di tahun 1960. Meski di tahun 1996 dengan lahirnya PP No. 40 Tahun 1996 tentang hak guna usaha, hak guna bangunan dan hak pakai atas tanah tetap menganut asas pemisahan horizontal. Kemungkinan penganutan asas perlekatan ini Seminar BPHN pada tahun 1977,35 yang dalam salah satu simpulan menyatakan: "Biarpun hukum tanah kita menganut asas pemisahan horizontal, akan tetapi karena penerapan tersebut harus sesuai dengan dan dapat menampung kenyataan dan kebutuhan dalam masyarakat, maka secara yuridis tidak ada keberatan bahwa hak tanggungan baik yang menggunakan peraturan hipotik maupun crediet verband, dibebankan atas tanah hak milik, hak guna bangunan, hak guna usaha berikut bangunan, alat-alat yang melekat secara nyata karena sifat, tujuan dan penggunaannya merupakan kesatuan dengan bangunan tersebut, dan tanaman yang telah dan akan ber- diri/tumhuh diatasnya, asal bangunan dan tanaman itu milik dari yang mempunyai tanah dan hal tersebut secara tegas dinyatakan didalam aktenya ".

Seminar BPHN tersebut mengandung pesan kemungkinan dianutnya dua asas tersebut dalam hukum agararia nasional. Hal ini juga dikemukakan oleh Mariam Darus ${ }^{36}$, bahwa pemerintah menganut accessie vertikal untuk hak atas tanah yang sudah memiliki sertifikat, sedangkan asas pemisahan horizontal dianut untuk hak atas tanah yang belum ada sertifikat. Dengan demikian pemerintah sendiri tidak bisa menutup mata untuk tetap menganut asas accessie sepanjang tanah itu tidak memenuhi pcrsyaratan formalitas dengan diterbitkannya sertifikat.

\section{PENUTUP}

Penganutan asas pemisahan horizontal dalam hukum agraria nasional sudah sejak awal sebagai konsekuensi dibangunnya hukum agraria nasional berdasarkan hukum adat. Asas pemisahan horizontal ini telah terwujud dalam kaidah-kaidah yang dituangkan dalam UUPA dan peraturan pelaksananya hingga tahun 2011, ketika dibentuk undang-undang rumah susun. Untuk kepentingan akademik atau pengajaran tentunya akan elok jika kedua asas ini di sampaikan dan bahas dalam pengajaran untuk memberikan pemikiran-pemikiran baru dan memberikan bukti pada mahasiswa bahwa hukum sesuai dengan cirinya selalu berkembang

\footnotetext{
35 F. Husni Hasbullah, 'Azas Pemisahan Horizontal (Horizontalle scheiding) dalam Hukum Tanah di Indonesia dan Permasalahannya' (1992) 22 (1) Jurnal Hukum dan Pembangunan $77-80$.

36 Mariam Darus Badrulzaman, Mencari Sistem Hukum Benda Nasional (Alumni Bandung 1983) 39.
} 
mengikuti volksgeist masyarakatnya. Namun juga asas yang sebaliknya yaitu asas perlekatan juga menjiwai hukum agararia nasional yang dapat dimengerti pada pengertian hak atas tanah yang definisinya oleh Boedi Harsono. 37 Penganutan asas perlekatan ini terus ada dan makin jelas nampak pada undang-undang rumah susun dan undang-undang hak tanggungan serta dalam praktek peralihan hak atas tanah yang dilakukan oleh PPAT dan dalam sistem pensertifikatan hak atas tanah dalam peraturan tentang pendaftaran tanah. Bahkan dalam satu undang-undang dianut dua asas itu sekaligus sebagai nampak pada undang-undang rumah susun. Penganutan asas perlekatan akan terus makin nyata digunakan ke depan. Oleh karena memang sangat bermanfaat bagi perkembangan perekonomian serta makin dimengerti bahwa sistem hukum selalu akan mengakar pada masyarakat. Dengan demikian kedua asas ini bersamasama diakui dan digunakan diaras pengaturan juga diaras prakteknya meski masih menyisakan permasalahan sebagaimana yang dikemukakan oleh Mariam Darus bahwa dimungkinkankah sertifikat atas bendabenda yang ada di atas tanah, meski hingga kini sistem pendaftaran tanah belum memungkinkan itu.

\section{DAFTAR BACAAN}

\section{Buku}

Dwiyatmi SH, Pengantar Hukum Indonesia (Ed. kedua, Ghalia Indonesia 2006).

Harsono B, Hukum Agraria Indonesia, Sejarah Pembentukan UndangUndang Pokok Agraria, Isi dan Pelaksanaanya (Ed. revisi, Djambatan 1999).

Hasan D, Lembaga Jaminan Kebendaan Bagi Tanah Dan Benda Lain yang Melekat Pada Tanah Dalam Konsepsi Penerapan Asas Pemisahan Horisontal(PT. Citra Aditya Bakti 1996).

Badrulzaman MD, Mencari Sistem Hukum Benda Nasional (Alumni 1983)

Perangin-Angin E, Hukum Agraria di Indonesia: Suatu Telaah Dari Sudut Pandang Praktisi (Rajawali 1986).

Siahaan MP, Hukum Bangunan Gedung di Indonesia (Rajawali Press 1998).

Sudiyat I, Hukum Adat Sketsa Asas (Liberty 1981).

Supriadi, Hukum Agraria (Sinar Grafika 2008).

Utsman S, Dasar-Dasar Sosiologi Hukum (Pustaka Pelajar 2007).

\section{Artikel Jurnal}

Hasbullah FH, Azas Pemisahan Horizontal (Horizontalle scheiding) dalam Hukum Tanah di Indonesia dan Permasalahannya, (1992) 22 (1) Hukum dan Pembangunan.

Ganindra DDM, dan Kurniawan F, 'Kriteria Asas Pemisahan Hoizontal Terhadap Penguasaan Tanah dan Bangunan' (2017) 32 (2) Yuridika.

Nasrullah, 'Analisis Hukum Secara Analogi Penerapan Asas Pemisahan Horizontal pada Praktek Jual Beli Tanah Tidak Beserta Dengan Pohon Kelapa di Atasnya di Kecamatan Patilanggio Kabupaten Pohuwato' (2018) 2 (2) Jurnal Hukum Volkgeist.

Rahmi E, 'Eksistensi Hak Pengelolaan atas Tanah dan Realitas

37 Boedi Harsono, Op.Cit. 
Pembangunan di Indonesia' (2010) 10 (3) Dinamika Hukum.

Rondonuwu G, 'Kepastian Hukum Peralihan Hak Atas Tanah Melalui Jual Beli Berdasarkan PP No. 24 Tahun 1997 tentang Pendaftaran Tanah' (2017) 5 (4) Lex Privatum.

Rubianti B, Pujiwati Y, Djakaria M, 'Asas Pemisahan Horizontal dalam Kepemilikan Hak Atas Tanah dan Bangunan Satuan Rumah Susun Bagi Masyarakat Berpenghasilan Rendah (MBR)' $\begin{array}{llll}\text { (2015) } & 17 & \text { (2) Jurnal }\end{array}$ Sosiohumaniora.

Sukardi, 'Politik Hukum Terhadap Penggunaan Hak Atas Tanah dan Bangunan Bagi Orang Asing di Indonesia' (1997) XII Yuridika.

\section{Peraturan Perundangan-undangan}

Undang-Undang Nomor 5 Tahun 1960 tentang Peraturan Dasar Pokok Pokok Agraria.

Undang-Undang Nomor 20 Tahun 2011 tentang Satuan Rumah Susun.

Undang-Undang Nomor 4 Tahun 1996 tentang Hak Tanggungan.

Undang-Undang Nomor 28 Tahun 2002 tentang Bangunan Gedung.

Peraturan Menteri Dalam Negeri Nomor 1 Tahun 1977 tentang Tata Cara Permohonan dan Penyelesaian Pemberian Hak atas Bagian - Bagian Tanah Hak Pengelolaan Serta

Pendaftarannya. 